\title{
Signalling for Status: UAE and Women's Rights
}

\section{Vânia Carvalho Pinto*}

\begin{abstract}
That societies should be gender-equal is a prevailing normative ideal to which states at the very least pay lip service. The UAE as a highly globalised state that aspires to a superior status has not stood outside of these dynamics. Whereas in the decades since independence in 1971 women's rights were emphasised as a sign of the country's progress, nowadays, the UAE government portrays women's rights as being advanced to such an extent that they are setting up a new gender empowerment benchmark for the Middle Eastern region. Additionally, the UAE has also proclaimed the goal of becoming one of the top 25 gender-equal states in the world by 2021. I suggest that these official proclamations are indicative of a signalling strategy whose aim is to advocate to an international audience that the UAE deserves a status higher than it currently holds. Based on Larson and Svechenko's interpretation of social identity theory, I claim that the UAE's strategy is one of social creativity. It rests on creating a new value - the Emirati standard of gender equality - within the Arab group. The former is operationalised through, on the one hand, 'teaching to the test' tactics in the area of women's political participation, a field that can be easily regulated by the government. And on the other, on overemphasising the professional deeds of a small group of high-achieving women. In the latter case, as the numbers of females in employment are rather low, the government elects to call attention to women in specific and unconventional positions so as to lend greater credence to the existence of their own superior standard of gender equality within the Arab region.
\end{abstract}

Keywords: United Arab Emirates; status-seeking strategies; gender equality; status signalling; women's rights.

\section{Introduction: signalling for higher status}

Located at the south-east end of the Arabian Peninsula, bordering Saudi Arabia and Oman, the United Arab Emirates (UAE) is a late newcomer into the international system. A collection of small regions (sheikhdoms) until 1971, it emerged as a united and oil-rich state upon the withdrawal of the United Kingdom from the region.

At the time, the leadership of the newly founded country saw statehood and international prestige as interconnected goals. Ideals of national progress and of nationwide 'betterment' were widespread to the extent that obtaining 'a higher international status [...]

* University of Brasília (UnB), Brasília-DF, Brazil; vcp.unb@gmail.com. ORCID iD 0000-0001-8323-5435. 
to take appropriate place among civilized states and nations' (Legal Advice Middle East n.d.) was inscribed into the Preamble of the Constitution. This goal became one of the most salient characteristics of the country's foreign policy. Indeed, throughout the years, the Emirates undertook costly endeavours that are associated with great power status (and geographically bigger countries). ${ }^{1}$ These include high military expenditure, such as the purchase of advanced weapons, as well as the development of both a space and a nuclear program. More recently, the UAE government has also proclaimed that it intends not only to become 'the best' country in the world by 2071, but also to be the first to build a human settlement on Mars by 2117 (Government.ae 2017a).

Gulf Studies academics have not been oblivious to these proclamations and developments. In fact, 'prestige' initiatives have been a common feature of the domestic and international policies not only of the UAE but also of its neighbours, especially Saudi Arabia and Qatar. These projects are commonly evaluated as springing from an interconnection of three elements, to which authors attribute more or less weight according to their analytical goals. These are to increase government legitimacy; to successfully compete with other Gulf neighbours; and to project soft power to international audiences (see, e.g., Sim 2011; Davidson 2012; Hertog 2017). These types of contributions have been exceedingly useful to advance our understanding of Gulf politics. However, in order to move forward towards greater analytical depth, I suggest that the Emirati case (and those of its Gulf neighbours) should be connected with specific International Relations literature on status-seeking strategies. It is an engagement that will refresh the study of Emirati foreign policy, hitherto cocooned within area studies scholarship. Indeed, considering that the study of small states' 'big ambitions' has already made its way into the literature (see, e.g., Neumann and De Carvalho (2015), on Norway; Crandall and Varov (2016) on Estonia; and Lamoreaux (2017) on the Baltic states) - it is highly valuable that non-western countries' foreign policies are also explored within this theoretical framework. By this token, the present article focuses on a rather salient dimension of Emirati foreign policy, that of the interface between women's rights and status-seeking strategies. The study of this particular topic is quite novel, both within UAE foreign policy and within IR literature on status-seeking strategies. ${ }^{2}$ However, despite this absence, current politics does offer us a myriad of empirical instances where women's rights and their status feature prominently in states' international strategies. Of the topics that have been the object of academic enquiry, we can reference, for instance, the ever-relevant theme of the place of gender both in the EU's enlargement policies (Pető and Manners 2006: 97-111) and in neighbourhood policies (Gündüz 2015; Kunz and Maisenbacher 2017). Similarly, Sweden's feminist foreign policy, which was enacted in 2015, has inspired not only academic papers (see Aggestam and Bergman-Rosamond 2016), but also like-minded governments to begin utilising the term. ${ }^{3}$

The UAE presents a very relevant case study to be explored within this overall topic. Indeed, throughout the early decades of its independence (from the 1970s onwards) it cast the rights of women as a sign of the UAE's progress (Carvalho Pinto 2012). Today, however, roughly in the past decade, the UAE is proclaiming that the rights of Emirati women have advanced to such an extent that the country is setting a new gender empowerment 
benchmark for the region (Ministry of State for Federal National Council Affairs [UAE] 2008: 12; al-Otaiba 2010). Nonetheless, official proclamations of the Emirates' superiority as regards women's rights have gone further than just aiming at regional supremacy; the country has also stated that it wants to become one of the top 25 gender-equal states in the world by 2021, i.e., in three years' time (Government.ae 2017b). Indeed, considering that in 2017 it stood at the $120^{\text {th }}$ position worldwide (World Economic Forum 2017a), to rise by 100 positions in such a short time span is a rather ambitious (and herculean) undertaking.

Given the above, I take these official proclamations as indicative of a status-signalling strategy, one that aims at advocating for an international status higher than the one it currently holds as regards women's rights. Indeed, the array of English-language documents and official proclamations that have been issued on this topic and their wide divulgation, as well as the spectacular goals that the government has set, does show that the UAE is seeking to attract international attention. Why this is so is a question I believe that needs to be explored with reference to the interrelation between the UAE's foreign policy and its nation-building project. But in order to do so, it is first necessary to garner, interpret and categorise the Emirates' actions in this field. This article is meant as a first step in that direction, which is to answer the question of why the UAE is making women's rights such a salient part of its foreign policy.

Therefore, this piece will be of interest to a number of audiences. These include those interested in the broader dynamics of Middle Eastern foreign policies (Gulf Arab policies in particular), as well as academics engaged in the study of states' status-seeking strategies, particularly those of small countries. For scholars that work at the node of international politics and women's rights, the present article suggests an analytical framework that has been hitherto unexplored within the academic field of the former. It is a frame that has the potential to further our understanding on the myriad of ways that states interpret and re-interpret women's rights in order to achieve their own foreign policy goals. The contributions provided by this study can then be generalised to similar cases as well as act as a resource for women's rights groups interested in better engaging with the politics of states and organisations in the international arena.

In the following I will provide a first foray into the study of the UAE's signalling strategy. I propose that its rationale is to cognitively induce a differentiation between the Emirates and the other Arab countries, so as to dissociate the former from a poor and supposedly homogenous 'Arab standard' of women's rights (see World Economic Forum 2017a). ${ }^{4}$ To that end, the UAE proclaims the existence of an Emirati standard that stands as an example in the Arab world. The strategy is operationalised by focusing on two issues: the number of women in politics; and calling attention to the professional achievements of a small group of women that are engaged in unconventional and/or high decision-making positions. As I will explain later in the article, these two are not the areas in which the UAE performs better. However, I believe they were chosen due to their potential in attracting international attention and therefore promoting status change. Hence, following this introduction, the article is structured roughly in three parts: the next section is an overview of the status-seeking literature with an eye on the framework put forward by 
Larson and Shevchenko (2010a, 2010b, 2014). The second one applies the above structure to the Emirati case and explores the ways by which the country is operationalising this strategy. The article will finish by summing up the argument and suggesting avenues for further research.

\section{Why international status is important}

As in human society, status is an important element of the relationship between states. As a set of shared beliefs about the relative position of each country, status determines which one gets what, when, and under what conditions. As perceptions that are collectively held, these views help clarify the rights, obligations and patterns of deference that a state may anticipate, as well as existing expectations in terms of one's behaviour towards dominant or subordinate states. The beliefs underlying status attribution are based on the value imputed to both material and immaterial attributes. Wealth, coercive capacities, culture, demographic position, socio-political organisation, diplomatic influence and a state's capacity to adhere to the civilisational standards of its time are but a few of those markers (Larson, Paul and Wohlforth 2014: 7, 20-21, 25; Neumann 2014: 85-114). ${ }^{5}$ This list of attributes is not absolute; symbols of high status and of stigma shift over time and assume differing forms according to cultural and geographical locations (Adler-Nissen 2014: 146; Zarakol 2014: 319-324; Renshon 2017: 36). Empire, for instance, was once valued as a marker of high standing, but it is no longer (Ward 2017: 824). The same can be said of female foot binding in China. Once a domestic marker of high status, it came to be considered by the Chinese elite as a symbol of the country's backwardness in the context of rising European encroachment (Appiah 2010: 53-100).

There is thus a double meaning underlying the concept of status: that of a state's standing - as a major power, for instance - and that of its rank, which is the state's ordinal position within a given hierarchy (Larson, Paul and Wohlforth 2014: 7). Differing hierarchies - each with its own metrics of legitimacy - feature several status groups competing for prominence (Clunan 2014: 288-289). Since status implies a favourable treatment - such as bestowed authority, modified behaviour (like deference or cooperation) - as well as symbolic acts (Weiss and Fershtman 1998: 802), its acquisition is seen as highly desirable (Larson, Paul and Wohlforth 2014: 25). Furthermore, once a state obtains a certain status, along with its accompanying privileges, it retains a presumptive right to that status which can outlast the initial conditions that gave rise to it (Larson, Paul and Wohlforth 2014: 19). ${ }^{6}$ Status is thus an important source of soft power that aids not only in the general pursuance of foreign policy objectives (Corbetta et al 2011: 218), but also in the boosting of a government's domestic legitimacy (Pu and Schweller 2014; Renshon 2017: 1). ${ }^{7}$ Once achieved, it can be drawn upon to further national interests in a myriad of areas ranging from agenda-setting power, to influence, access and even material benefits (Jakobsen, Ringsmose and Saxi 2018: 2). The UAE's contribution to the ISAF Afghanistan mission, for instance, is a telling example. Their support for the fight against terrorism was highly appreciated in Washington. This translated into the latter's assistance for the UAE to out- 
bid Germany in the international competition to host IRENA, the International Renewable Energy Agency (Carrington 2016).

Debora Larson and Alexei Shevchenko (2010a, 2010b, 2014) have put forward one of the most widely used frameworks for the study of states' status-seeking strategies. ${ }^{8}$ They draw on social identity theory's (SIT) study of intergroup behaviour, understood as a struggle over the relative status or prestige of one's in-group (Tajfel 1982; Tajfel and Turner 1986; Hogg and Abrams 1988, 1998). Higher status groups fight to protect their evaluative superiority, while lower status groups struggle to shed their social stigma and promote their positivity. The strategies that groups adopt to manage their identity depend on subjective belief structures, i.e., members' beliefs about the nature of the relationship between their group and a specific out-group (Hogg 2016: 3, 7). Taking their cue from this literature, Larson and Shevchenko (2014: 2) proposed that states that are unsatisfied with their international positioning could pursue three types of strategies that are not mutually exclusive. These are: a) social mobility - by emulating more advanced states; b) social competition - by trying to replace the highest placed state through the acquisition of military and economic power; and c) social creativity - by finding an alternative arena where they can demonstrate superiority. A crucial difference between these strategies as proposed by SIT and by Larson and Shevchenko is that SIT considers the mobility strategy as individual and the other two as collective. Larson and Shevchenko, in contrast, collapsed the distinction between individual and collective strategies by considering them all as collective, i.e., pursued by a state understood as a group of people. ${ }^{9}$ Altogether, these are ideal types, and elements of all three can be found in any given country's foreign policy (Larson and Shevchenko 2010b: 74-76).

Accordingly, states will engage in social mobility by acquiring the attributes of more advanced states as a means to cast aside their inferior social identity (Hogg and Abrams 1998: 24). Both SIT and IR literature caution that this tactic is seldom successful, as its effectiveness is dependent upon the dominant members' willingness to accept new members. This is illustrated in several empirical cases: Larson and Shevchenko (2010b) have explored Russia’s failed strategy in this regard; and Ayşe Zarakol (2011) has looked at the unsuccessful attempts of Turkey, Japan and Russia in different time periods. Those few that are allowed to pass, it is argued, are solely meant to feed the myth of mobility and end up becoming tokens (Hogg and Abrams 1998: 25). The second strategy, that of social competition, entails the removal of the highest-ranking element within the hierarchy. However, in their translation into IR, Larson and Shevchenko (2010b: 73) restricted the application of this approach solely to the economic and military domains. The final strategy - social creativity - entails the redefinition of the values and attributes of the subordinate element(s) (Hogg 2016: 7). Henri Tajfel and John Turner (1986: 19-20) suggested that social creativity can unfold in three ways - a) by introducing a more favourable dimension of comparison; b) by changing the target of comparison; and c) by changing the values assigned to the attributes. As regards the first, a) can be achieved by introducing dimensions such as foreign aid as a measure of comparison; b) is an approach whereby the seeking state avoids (upward) comparisons with higher status groups and instead engages in (lateral or downward) evaluations with others lower in the social pecking order 
(Hogg 2016: 7). Therefore, by changing the reference of comparison, the relevant inferiority decreases in salience. This is the case when a state, instead of comparing itself with great powers, chooses neighbours of less prominence. The third, c), is about changing the values assigned to the attributes of the state. An illustrative example of both b) and c) is offered by Peter Gris (2005: 252-252) in his study of China. He explains how China avoids great power comparisons by engaging in more favourable comparisons with its East Asian neighbours (downward/lateral appraisal) and how the understanding of Confucian tradition mutated from 'feudal' and 'backwards' into the heart of China's civilisation.

The underlying goal of the strategies described above is to change a certain status belief among the political actors that the seeking state considers of relevance. Signalling thus entails an assertive type of information transmission whereby the seeking state undertakes to attract other states' attention through diplomatic activity, repeated proclamations, ample use of rhetoric, and acquisition of status symbols (Larson, Paul, and Wohlforth 2014: 22; Neumann and De Carvalho 2015: 1-21; Pu 2017: 149). The following section details the UAE's tactics in this regard.

\section{Signalling: Emirateness as a(n) (superior) Arab standard}

In signalling for a higher status, states will inflate their strengths while devaluing their shortcomings. In the case at hand, the UAE chooses not to mention the fact that it is among the bottom 24 countries in closing the gender gap (ranked at number 120 out of 144 countries) (World Economic Forum 2017a) ${ }^{10}$ and calls attention instead into its third place within the Middle East and North Africa group (World Economic Forum 2017b). The government takes this ordinal position as a basis to claim regional leadership as regards women's rights (al-Otaiba 2010). It is a pre-eminence, the argument goes, that renders comparisons of the UAE's situation with those of other Arab states both undue and unjust. ${ }^{11}$ After all, as the government claims, the Emirati situation is 'an example that stereotypes on Arab women do not apply in the UAE' (Ministry of State for Federal National Council Affairs [UAE] 2008: 2). Indeed, the UAE claims to be a regional pioneer in women's empowerment and as having acquired 'an outstanding rank among the countries in the region in this field' (see, e.g., Ministry of Foreign Affairs [UAE] 2014: 2, 4). This model - the Emirati standard - is presented as being based on gender equality, which is quite surprisingly (and unprecedentedly) claimed to be an Emirati tradition (see Ministry of Foreign Affairs [UAE] 2015b: 3). Such characteristics would make the UAE 'a shinning [sic] model' (Ministry of Foreign Affairs [UAE] 2015a: 2) for the region and the world in terms of women's empowerment (Ministry of Foreign Affairs [UAE] 2015b: 3-4). As the above shows, the underlying rationale of the UAE's signalling strategy is that of both difference and superiority vis-à-vis the other Arab states, but all the while firmly remaining within this regional grouping. This evidences that the UAE is not attempting to pass into another status group (which would be characterised as social mobility) ${ }^{12}$ and that it is not seeking to dislodge any particular countries from a high-ranking position (social competition). ${ }^{13}$ Rather, in omitting references to its global position and stressing a regional one instead, the UAE is emphasising another hierarchy, one in which it performs substantially better 
(see Larson and Shevchenko 2010b: 73-75). Therefore, the UAE is choosing to proclaim a new 'Arab attribute': the Emirati standard. Both actions - choosing a less prominent group for comparison and, within this Arab rank, changing an attribute, i.e., proclaiming a unique Emirati model - constitute a strategy of social creativity.

This strategy unfolds by focusing on two areas: political participation and high-ranking/unconventional female employment (not general employment numbers). These are not the areas where the country ranks more favourably, which would render them, at least in theory, more suitable for signalling. ${ }^{14}$ However, as mentioned previously, to have greater numbers of women both in the job market and in politics is in public perception, closely associated with empowerment. This means that by focusing on these two areas, there is a greater potential of inducing a change in status belief. This reasoning is key in signalling strategies: given the array of topics that engage the political leaders' attention, the signalling state must undertake actions, which are visible, salient and unambiguous (Renshon 2017: 24). In this regard, the UAE has turned the cases and information that underlie the signalling strategy into spectacular media affairs, particularly in what concerns women's employment in unconventional areas.

\section{Building the Emirati standard of women's rights:}

\section{i) Politics: the art of nominating 'enough' women}

As previously mentioned, political participation is taken as being highly associated with female empowerment. This means that the greater the number of women in politics, the higher the chances for the UAE to acquire a higher status. But more to the point, however, is that these are numbers that the Emirati government can easily produce because it controls political participation. In this sense, the government benefits from the fact that international indexes that look at legislative representation do not differentiate between elected and appointed officials, or between parliaments that have effective legislative power and bodies that are merely consultative. This means that UAE can benefit from the categorization by nominating (rather than electing) women into its consultative council (which for international comparison purposes will still be considered a parliament). My claim is that, within this area, the UAE follows 'teaching to the test' tactics by nominating just enough women so as to guarantee that the UAE would make the top positions in the political participation regional ranking. My point will be illustrated bellow.

Partial elections were introduced in 2006 for the election of half the members of the Federal National Council (FNC), i.e. twenty out of forty. Until then, royal nomination offered the only path to federal and emirate-level decision-making positions. At the time, the government determined (and continued to do so also in the subsequent 2011 and 2015 elections) who could participate in this process as voters. It would then be up to those specific individuals whether they wanted to run as candidates. Even though the relative numbers of those entitled to vote has continued to rise in each subsequent election, the criteria for selection are quite unclear and continue to be contested (see, e.g., Habboush 2011). In each of the three elections, only one woman succeeded in garnering the popular 
vote. However, in each of these instances, the local emirate governments nominated a few women under their quota. This meant that in 2006, with the nomination of eight other women (bringing the total to nine), the UAE entered the ranking of women's political participation in the Arab world straight into third place (22.5\%), behind Israel and Tunisia (Hausmann, Tyson and Zahidi 2007). In the subsequent election, in 2011, six more were nominated. At $17.5 \%$ (seven women), the UAE fell in the regional ranking to fourth place (Inter-Parliamentary Union 2011); and in 2015, the UAE returned to the $22.5 \%$ mark, with the total of nine women (again with eight of them nominated). However, this time, the UAE fell into fifth position, behind Tunisia, Israel, Algeria and Iraq, one that it still occupies at the time of writing (Inter-Parliamentary Union 2018). None of the countries cited belong to the Gulf region, which means that the UAE can claim sub-regional supremacy in its immediate neighbourhood. Before 2006 no women had been nominated for the FNC. This means that in a period of twelve years there has been an evolution in the percentage of women in politics from zero to $22.5 \%$.

Nominations for the cabinet of ministers have followed a similar trend. The first woman to join it was Sheikha Lubna al-Qassimi in 2005. A member of the Sharjah royal family, her appointment was not seen as a statement on women's political participation, as the awarding of government portfolios to members of the royal families was and continues to be common practice. Since this nomination, the number of women ministers has been rising steadily, and in 2009, the UAE reached the top spot in the Arab world with 18\% women ministers, a leadership position that it still holds. The country now has nine women in a thirty-one-member cabinet, which corresponds to 29\% (Inter-Parliamentary Union 2017; Government.ae 2018). The discretionary ability to nominate and compose both the FNC and the cabinet has thus been central for this regional primacy, a feat made possible by the nature of the Emirati political system (see, e.g., Davidson 2012).

\section{ii) Obscuring the realities of employment: focus on 'trailblazing' women}

In this other dimension of the signalling strategy, the government again highlights (or creates) strengths and undervalues limitations ( $\mathrm{Pu}$ 2017: 149-150). In fact, the rate of women employed is quite low, lying at just $12.4 \%$ in 2017 . It should be mentioned that in 1990 , the percentage was $11.1 \%$ (The World Bank 2017), which brings an increase of a mere $1.3 \%$ in a period spanning almost thirty years. These figures for female employment are hardly noteworthy, which would beg the question of why the UAE is focusing on this arena and not on successful areas such as illiteracy eradication (see endnote 13). The answer I volunteer is that the employability of women is also a key parameter of female empowerment. Usually, the more women there are in the labour force, the more empowered they are assumed to be. The UAE, however, cannot signal a change of status based on such a low percentage. However, these numbers are common across the Arab Muslim countries and can be explained, in very general terms, by referring to cultural norms and economic circumstances. Even though these countries differ wildly in their socio-economic conditions, they do have in common the fact that culturally, women's roles are primarily defined with reference to the private sphere. Employment is not necessarily seen as essential - 
again varying with the socio-economic status of families. Oftentimes, is seen at best as a complement to the household's budget, and at worse as an unwelcome distraction from more relevant family duties. Within the Gulf context, female modesty and seclusion still brings about social status, and the Emirati government itself treads this line rather carefully. ${ }^{15}$ Within this general background of low female employment and cultural resistance to it, high numbers are difficult to produce. Given that the government could not change this situation in a short timeframe, it has resorted to the unabashed advertisement of the professional achievements of a small group of women. This is a very heterogeneous group made up of public intellectuals, university professors, MPs, ministers, engineers, flight pilots, surgeons, and diplomats, among others. They are commonly known in the media and in academic works as leaders or trailblazers. The study of their lives and ideas currently makes a rather salient branch of research on Gulf women (see, e.g. Augsburg, Claus and Randeree 2009; Gleissner 2017). In common they have high academic qualifications and/or a public profile, and/or occupy a high decision-making position and/or work in a predominantly male field.

Emirati newspapers always run interviews and praiseworthy stories about their perseverance, and frame their achievements in nationalistic terms. ${ }^{16}$ They are depicted as the symbols of the Emirati standard - thus making the point that UAE women have the highest status in the Arab world - and are held as symbols of the country's ability to compete globally and succeed. I shall refer to a recent famous case, that of Emirati Major Maryam al-Mansour. Featured in the front pages of several international newspapers in 2014, she was celebrated as the first Arab female fighter pilot, who in addition had also participated in the bombing of ISIS targets. ${ }^{17}$ Authors Ilhem Allagui and Abeer Al-Najjar (2018: 70-74) analysed the imagery of the photos of al-Mansour that were distributed to the western media and drew attention to some unusual elements in al-Mansour's uniform. These were a head covering hijab - signalling adherence to religious norms - and a UAE flag on her helmet, making her nationality clear. According to the authors, the specific elements of her uniform were meant to create an iconic picture of social change directed at a western audience so as to differentiate the UAE from a 'repressed Arabia' (Allagui and Al-Najjar 2018: 79). I would say that the USA features expressively within that intended western audience. This would be in line with other dimensions of UAE foreign policy and would help explain why the UAE's Washington-based embassy is, to my knowledge, the only one that displays an extensive reservoir of information about the status of Emirati women. It features a section entitled 'Women in the UAE' that highlights the achievements of the trailblazers (with a few video interviews), and hails women's presence in politics and high decision-making positions (Embassy of the United Arab Emirates 2018). In this sense, the status-signalling strategy as regards women's rights could be explained as a 'soft' dimension to more general Emirati security strategies towards the USA. Indeed, the embassy website features a link to a separate page on USA-UAE relations) ${ }^{18}$ that begins with the sentence that both countries have 'common values and a shared outlook for a better future.' Beliefs about the rights of women belong to a common values approach, and would thus inform a 'natural' alliance among like-minded countries. This analytical departure point already features in the security literature on the status-seeking strategies of small 
states. This claims that these strategies are directed at great powers so as to ensure that, if needed, recognition could be translated into protection (see Neumann/De Carvalho 2015; Jakobsen, Ringsmose and Saxi 2018). In this sense, the extent to which status-enhancement strategies in 'soft' areas could function towards similar goals would be a path worth exploring in separate contributions. ${ }^{19}$

In addition to al-Mansour, other high-profile women include Hind Abdulaziz Alowais and Ohood al-Roumi, the former nominated to UN Women as a senior advisor and the latter to the Global Entrepreneurship Council. In the latter case, al-Roumi became the first Arab member of the body. In both cases, the UAE framed these nominations as recognition of its 'leading women's rights role at the global level' (WAM 2015a; WAM 2015b). It should be mentioned that the words 'global' and 'regional' occur several times. While the regional ranking is being used as a trampoline for a higher status claim, aspirations for a substantially better position in the global ranking are also being transmitted as the ambition to be one of the top 25 gender-equal states, as mentioned before, evidences.

In sum, the main lines of the strategy are synthesised in the table below:

Table 1: Synthesis of the UAE government's signalling strategy as regards women's rights.

\begin{tabular}{lll}
\hline Social creativity & Fields of operationalisation & Approaches \\
\hline $\begin{array}{l}\text { Emphasising the Arab } \\
\text { regional ranking } \\
+\end{array}$ & $\begin{array}{l}\text { Political participation } \\
\begin{array}{l}\text { New value: Emirati } \\
\text { standard of women's } \\
\text { rights }\end{array}\end{array}$ & $\begin{array}{l}\text { Teaching to the test by nominating enough } \\
\text { women as ministers and parliamentarians }\end{array}$ \\
\cline { 2 - 3 } & Unconventional/high & $\begin{array}{l}\text { Diverting attention from general numbers by } \\
\text { calling attention to women in these fields }\end{array}$ \\
\hline
\end{tabular}

Source: created by the author.

\section{Summing up and avenues for further research}

In answering the question of why the UAE is making women's rights such a salient part of its foreign policy, my answer is that it is doing so in order to signal for a higher status, which is part of its broader strategy for international prominence, with roots going back to its founding (see Preamble of the Constitution in the Introduction).

Therefore, this piece presented a first incursion into the identification and explanation of this tactic. I have proposed that the UAE's status-enhancing strategy is one of social creativity based on a two-pronged approach: on the one hand, emphasising its leadership within an Arab ranking (while not referencing the less favourable global one); and on the other ascribing value to a newly minted Emirati standard of gender equality, a model promoted as being uniquely advanced in the Arab world. As predicted in the literature, the UAE sought to overstate positive features, while overlooking or undervaluing negative ones. This was reflected in the areas chosen for the signalling strategy: to hail the number of females in politics and to call attention to and celebrate the professional achievements of a small group of women. These were not the UAE's strongest points; but these are the 
areas that are most closely associated with female empowerment and thus the ones that had a better chance of attracting international attention.

As regards the first, thanks to teaching to the test nomination strategies (and to the international indexes' lack of differentiation between nominated vs. elected members, and elected parliaments vs. consultative bodies), the UAE was able to enter the ranking of women in Arab parliaments directly in third place in 2006, oscillating between fourth and fifth position in the elections that followed in 2011 and 2015. Even though it cannot claim an absolute regional supremacy in this regard - since countries such as Tunisia, Israel, Iraq and Algeria are, at the time of writing, ahead of the UAE - it can do so within the Gulf area. The number of women in cabinet positions has been rising much faster, which has led the country to the top position within the Middle Eastern region.

In what concerns the second area of engagement, the low figure for employed women are ignored, the country choosing instead to call attention to the deeds of a small group of women who are engaged in unconventional and/or high decision-making positions. By thoroughly advertising these cases, the government hopes to induce a perception of empowerment of UAE women. The question that follows is to what extent are they succeeding? Preliminary research indicates that this signalling strategy has problems of resonance (see endnote 10). However, further study in this field must carefully delimitate the audience under study - 'western' audience is too large an object - so as to identify fields of engagement between the UAE and the selected addresses that could bear on the perception/understanding awarded to the signalling strategy. As mentioned in the piece, to explore whether the women's rights status-signalling strategy could be regarded as a 'soft' dimension to more general Emirati security strategies, particularly towards the USA, would be a theme worth investigating. Indeed, within broader Emirati foreign policy, one can observe that gender equality is merely one of the many areas where the UAE seeks to achieve regional (and oftentimes global) prominence. To become the 'best' country in the world by 2071 and to build the first human settlement in Mars in 2117 are cases in point. In this sense, the UAE constitutes an ideal case study of a small country's status-seeking strategies, one that defies conventional literature as regards the supposedly unambitious policies of small states. ${ }^{20}$ Indeed, following Wohlforth et al (2017: 17), status seeking is more than a great power game; it permeates the entire international system. To this, I would add that it even affects micro-estates. The UAE thus stands as a significant case of a country that despite not faring well in international indexes of women's rights still utilises them selectively to build positive differentiation into its status policies. It is a theme that lends itself to relevant academic inquiry to both gender and IR scholars.

\section{Notes}

1 On status and great power behaviour see, e.g., Volgy et al (2011).

2 Even though the specific literature on status has not been tackled by gender scholars, there are works, within both area studies and IR, that utilise affiliated concepts such as 'civilisation,' 'modernity' and 'progress' as a means to relay the idea of state status as a result of the expansion of the rights of women (see, e.g., Towns 2007, 2016; Jayawardena 1994).

3 I am referring to the cabinets of Pedro Sanchez and of Justin Trudeau, in Spain and in Canada, respectively. 

UNDP and Freedom House devoted whole reports to Arab women's (lack of) rights, with no counterpart for other regions of the world, further contributed to these perceptions.

5 For conceptual reviews of associated concepts such as reputation, honour, respect and authority, see Lawson and Renshon (2017: 37-40); Wolf (2011: 105-142); Larson, Paul, and Wohlforth (2014: 13-17); Lake (2014: 246-272); and Clunan (2014: 273-296).

6 See Bertrand Badie's (2011: 97-114) analysis of France's pursuit of status beyond resource capabilities.

7 Even though the domestic dimension is not the object of this piece, there is a distinct political legitimation strategy at stake here. Women's achievements are credited to the vision of both the founder of the UAE, Sheikh Zayed al-Nahyan, and the current rulers who made them possible (see, e.g., al-Nowais 2018; Nasir and Zakaria 2018). By the same token, the eases of the present - as produced by the state - are always favourably compared with the difficulties of life pre-state (see, e.g., Underwood 2014). This framing strategy - of always underlining the decisive role of the leadership -applies to all areas of action, from humanitarian aid to national volunteering projects, to engagement in sub-regional security initiatives.

8 Since 2014 there were at least twenty-seven articles in thirteen journals that applied this framework (Ward 2017: 822).

9 For recent criticism of Larson and Svechenko's formulation, see Steven Ward (2017).

10 The country's scorecard is available here: http://reports.weforum.org/feature-demonstration/files/2016/10/ ARE.pdf

11 Two examples stand out in this regard. The first was the reaction of the UAE Minister of State for Foreign Affairs Anwar Gargash to the European Parliament's criticism of the country's human rights situation. He branded the former's knowledge of the status of women as 'surprisingly uninformed' and 'rather superficial' (Gargash 2012). A second case features Mona al-Marri, Chairwoman of the Dubai Women Establishment, an official body of the Dubai government. She complained that while at an international conference, the UAE was confused with countries that featured 'poor educational levels, cultural issues and early marriages' (Al Khoori 2014). One can find several articles in the Emirati press defending the UAE women's rights situation vis-à-vis other Arab countries (see, e.g., The National 2014; Gornall 2014).

12 The UAE could not simply adhere to a western liberal gender regime without critically dissociating itself from key cultural and religious values, a step that would also have important domestic consequences in terms of loss of legitimacy.

13 According to Larson and Svechenko's framework, such movement is limited to the economic and military arenas. If this were an instance of competition - which I suggest it is not - this empirical case would remain uncategorised. It is a problem in the translation of the framework from SIT to IR to which Ward (2017) has already called attention.

14 Despite a low overall position, the country features a couple of successes in closing the gender-gap, in both the literacy rate and the sex ratio at birth. The UAE occupies the top world spot ex-aequo with Norway and Sweden in the first case, and ex-aequo with Norway in the second.

15 The National Vision 2021, a document that charts the government's vision for the development of the UAE for the following decade, is a case in point. The promotion of professional opportunities for women is mentioned solely in passing, worded in a very broad manner and within a section that deals with family cohesiveness (Vision 2021, 2018).

16 See, e.g., the stories of Houriya Kazim, the first female Emirati surgeon (Ghazal 2014a), and of Hessa al Ossaily, the first woman TV presenter (Ghazal 2014b).

17 See, e.g., Max Fisher's (2014) article on Vox and Ishaan Tharoor's (2014) on the Washington Post.

18 See: https://www.uaeusaunited.com

19 William Wohlforth and colleagues (2017) have utilised the case of Norway to suggest that a country can acquire status by presenting itself as a 'moral' state. While they do not mention women's rights, being a good ally and showing solidarity are cases they highlight. In this regard, see also Carvalho Pinto (2017).

20 See Jeremy W. Lamoreaux's (2014) article on Russia and the Baltic States; Matthew Crandall and Ingrid Varov (2016) on Estonia; and Khalid S. Almeizaini and Jean-Marc Rickli's (2016) edited volume on the Gulf States' foreign policies. 


\section{References}

Abu-Lughod, Lila. 2009. 'Dialects of Women's Empowerment: The International Circuitry of the Arab Human Development Report 2005.' International Journal of Middle East Studies 41 (1): 83-103. Adely, Fida J. 2009. 'Educating women for development: The Arab Human Development Report 2005 and the problem with women's choices.' International Journal of Middle East Studies 41 (1): 105-122.

Adler-Nissen, Rebecca. 2014. 'Stigma management in International Relations: Transgressive identities, norms and order in international society.' International Organization 68 (1): 143-176.

Aggestam, Karin and Annika Bergman-Rosamond. 2016. 'Swedish feminist foreign policy in the making: Ethics, politics, and gender'. Ethics and International Affairs 30 (3): 323-334.

Al Khoori, Ayesha. 2014. 'Mona Al Marri on mission to change minds about UAE women.' The National [online] 25 October. At http://www.thenational.ae/uae/mona-al-marri-on-mission-tochange-minds-about-uae-women [Accessed 19 October 2017].

Allagui, Ilhem and Abeer al-Najjar. 2018. 'From women empowerment to nation branding: A case study from the United Arab Emirates.' International Journal of Communication 12: 68-85.

Almeizaini, Khalid and Jean-Marc Rickli (eds). 2016. The Small Gulf States: Foreign and Security Policies Before and After the Arab Spring. London/New York: Routledge.

Al-Otaiba, Youssef. 2010. 'In conversation: UAE Ambassador Yousef Al Otaiba'. Interview by Jeffrey Goldberg. Aspen Ideas Festival [online], 6 July. At https://www.aspenideas.org/session/conversation-uae-ambassador-yousef-al-otaiba [Accessed on 12 December 2015].

Appiah, Kwame A. 2010. The Honor Code. How Moral Revolutions Happened. New York/London: W.W. Norton \& Company.

Augsburg, Kristin, Isabell A Claus and Kasim Randeree. 2009. Leadership and the Emirati Woman. Breaking the Glass Ceiling in the Arabian Gulf, Vol. 1. Münster: LIT Verlag.

Badie, Bertrand. 2011. 'French power-seeking and overachievement.' In Thomas J Volgy, Renato Corbetta, Ryan G Baird, and Keith A Grant (eds), Major Powers and the Quest for Status in International Politics. Global and Regional Perspectives. Basingstoke: Palgrave MacMillan, pp. 97-114.

Carrington, Damian. 2010. 'WikiLeaks Cables: US backs UAE bid to host Green Energy Agency.' The Guardian [online], 3 December. At http://www.guardian.co.uk/environment/2010/dec/03/us-uaegreen-energy-irena/print [Accessed on 2 September 2016].

Carvalho Pinto, Vânia. 2017. 'Em busca de status: A participação dos Emirados Árabes na missão ISAF-Afeganistão da OTAN.' In André Araújo, Arthur Assis and Sérgio da Mata (eds), Entre filosofia, história e relações internacionais. Escritos em homenagem a Estevão de Rezende Martins. São Paulo: Sociedade Brasileira de Teoria e História da Historiografia/LiberArs.

2012. Nation-Building, State and the Genderframing of Women's Rights in the United Arab Emirates (1971-2009). Reading: Ithaca Press.

Clunan, Anne L. 2014. 'Why Status matters in world politics.' In T V Paul, Deborah Welch Larson and William C Wohlforth (eds), Status in World Politics. Cambridge: Cambridge University Press, pp. 273-296.

Corbetta, Renato, Ryan G Baird and Keith A Grant. 2011. 'Status and the future of international politics.' In Thomas J Volgy, Renato Corbetta, Ryan Baird and Keith A Grant (eds), Major Powers and 
the Quest for Status in International Politics. Global and Regional Perspectives. Basingstoke: Palgrave MacMillan, pp. 1-26.

Crandall, Matthew and Ingrid Varov. 2016. 'Developing status as a small state: Estonia's foreign aid strategy'. East European Politics 32 (4): 405-425.

Davidson, Christopher. 2012. After the Sheikhs: The coming collapse of the Gulf Monarchies. London: Hurst.

The National [online]. 2014. 'Emirati women fight ignorance.' 26 October. At https://www.thenational.ae/opinion/emirati-women-fight-ignorance-1.658898 [Accessed on 18 January 2018].

Embassy of the United Arab Emirates. 2018. Women in the UAE. Washington, DC. At https://www. uae-embassy.org/about-uae/women-uae [Accessed on 22 August 2018].

Fisher, Max. 2014. 'The condescension and racism behind American praise of the female pilot who bombed ISIS.' Vox [online], 26 September. At https://www.vox.com/2014/9/26/6845019/maryamal-mansouri-uae-pilot-bombed-isis-praise-racist [Accessed on 29 January 2018].

Gargash, Anwar. 2012. 'Debate in European Parliament misreads UAE's progress.' The National [online], 13 November. At http://www.thenational.ae/thenationalconversation/comment/debate-in-european-parliament-misreads-uaes-progress\#full [Accessed on 26 September 2015].

Ghazal, Rym. 2014a. 'History Project: The first female Emirati surgeon is fighting fit.' The National [online], 1 December. At https://www.thenational.ae/uae/heritage/history-project-the-first-femaleemirati-surgeon-is-fighting-fit-1.332687 [Accessed on 29 January 2018].

2014b. 'History Project: The mother of UAE media, Hessa Al Ossaily. The National [online], 1 December. At https:/www.thenational.ae/uae/heritage/history-project-the-mother-of-uae-media-hessa-al-ossaily-1.651459 [Accessed on 12 January 2018].

Gleissner, Xenia. 2017. 'Women as representations of class and modernity: Gendered public visibility on Abu Dhabi TV. In Elena Maestri and Annemarie Profanter (eds), Arab Women and the Media in Changing Landscapes. Cham: Palgrave (Springer Nature), pp. 57-74.

Government.ae: The Official portal of the UAE Government. 2017a. '2030-2117'. 28 September. At https:/government.ae/en/more/uae-future/2030-2117 [Accessed on 14 November 2018].

2017b. 'Women. 6 November. At https:/government.ae/en/information-and-services/social-affairs/women [Accessed on 12 January 2018].

2018. 'The UAE cabinet.' 9 July. At https://government.ae/en/about-the-uae/the-uae-government/the-uae-cabinet [Accessed on 22 August 2018].

Gris, Peter Hays. 2005. 'Social psychology and the identity-conflict debate: Is a 'China threat' inevitable?' European Journal of International Relations 11 (2): 235-265.

Gornall, Jonathan. 2014. 'Women and war: Fighting misconceptions of sex.' The National [online], 30 September. At https:/www.thenational.ae/uae/government/women-and-war-fighting-misconceptions-of-sex-1.636896 [Accessed on 12 January 2018].

Habboush, Mahmoud. 2011. 'UAE nationals ask: Why can't we all vote?' 21 September. Reuters [online] At https://www.reuters.com/article/us-emirates-elections-campaign-idUSTRE78K33F20110921 [Accessed on 22 August 2018].

Hausmann, Ricardo, Laura D Tyson and Saadia Zahidi. 2007. The Global Gender Gap Index 2007. At http://www.pariopportunita.provincia.tn.it/filesroot/Documents/perSaperneDiPiu/index2007gender\%20gap\%20explanation.pdf [Accessed on 22 August 2018]. 
Hertog, Steffen. 2017. 'A quest for significance: Gulf oil monarchies' international 'soft power' strategies and their local urban dimensions.' LSE Kuwait Programme Paper Series 42: 1-26.

Hogg, Michael A. 2016. 'Social Identity Theory'. In Shelley McKeown, Reeshma Haji and Neil Ferguson (eds), Understanding Peace and Conflict Through Social Identity Theory. Contemporary Global Perspectives. Berlin: Springer, pp. 3-17.

Hogg, Michael A and Dominic Abrams. 1998. Social Identifications. A Social Psychology of Intergroup Relations and Group Processes. London/New York: Routledge.

Inter-Parliamentary Union. 2011. 'Women in national parliaments. Situation as of 31 December 2011.' At http://archive.ipu.org/wmn-e/arc/classif311211.htm [Accessed on 15 November 2018].

2017. 'Women in Politics 2017'. At https://www.ipu.org/resources/publications/infographics/2017-03/women-in-politics-2017 [Accessed on 12 January 2018].

2018. 'Women in Parliaments. Situation as of 1st October 2018.' At http://archive.ipu.org/ wmn-e/arc/classif011018.htm [Accessed on 15 November 2018].

Jakobsen, Peter Viggo, Jens Ringsmose and Håkon Lunde Saxi. 2018. 'Prestige-seeking small states: Danish and Norwegian military contributions to US-led operations.' European Journal of International Security 3 (2): 256-277.

Jayawardena, Kumari. 1994. Feminism and Nationalism in the Third World. London: Atlantic Highlands; New Jersey: Zed Books.

Lake, David A. 2014. 'Status, authority, and the end of the American Century'. In T V Paul, Deborah Welch Larson and William C Wohlforth (eds), Status in World Politics. Cambridge: Cambridge University Press, pp. 246-272.

Kunz, Rahel and Julia Maisenbacher. 2017. 'Women in the neighbourhood: Reinstating the European Union's civilising mission on the back of gender equality promotion?' European Journal of International Relations 23 (1): 122-144.

Lamoreaux, Jeremy W. 2014. 'Acting small in a large state's world: Russia and the Baltic states.' European Security 23 (4): 565-582.

Larson, Deborah Welch, T V Paul and William C Wohlforth. 2014. 'Status and world order.' In T V Paul, Deborah Welch Larson and William C Wohlforth (eds). Status in World Politics. Cambridge: Cambridge University Press, pp. 3-32.

Larson, Debora and Alexei Shevchenko. 2014. 'Russia says no: Power, status, and emotions in foreign policy.' Communist and Post-Communist Studies xxx: 1-11.

2010a. 'Status concerns and multilateral cooperation.' In I William Zartman and Saadia Touval (eds), International Cooperation: The Extents and Limits of Multilateralism. Cambridge: Cambridge University Press, pp. 182-207.

Larson, Debora and Alexei Shevchenko. 2010b. 'Status seekers. Chinese and Russian responses to U.S. primacy'. International Security 34 (4): 63-95.

Legal Advice Middle East. n.d. 'Laws and Regulations: The Constitution of the United Arab Emirates.' At https://legaladviceme.com/legislation/120/uae-constitution-of-united-arab-emirates [Accessed on 25 January 2018].

Nasir, Sarwat and Sherouk Zakaria. 2018. 'Emirati Women's Day: 'We owe to Sheikh Zayed, his vision and efforts." Khaleej Times [online], 28 August. At https://www.khaleejtimes.com/news/gen- 
eral/emirates-womens-day-we-owe-to-sheikh-zayed-his-vision-and-efforts-- [Accessed on 17 November 2018].

Al-Nowais, Shireena. 2018. 'Emirati Women's Day: UAE women hailed for "enriching the nation." The National [online], 28 August. At https://www.thenational.ae/uae/government/emirati-womens-day-uae-women-hailed-for-enriching-the-nation-1.764294 [Accessed on 17 November 2018].

Ministry of State for Federal National Council Affairs [UAE]. 2008. Women in the United Arab Emirates: A Portrait of Progress. Abu Dhabi. At http://www.uae-embassy.org/sites/default/files/Women in_the_UAE_Eng.pdf [Accessed on 20 September 2015].

Ministry of Foreign Affairs [UAE]. 2014. MOFA Brief on Emirati Women Empowerment on Occasion of International Women's Day. Abu Dhabi. At https://www.mofa.gov.ae/EN/Documents/3564.pdf [Accessed on 23 August 2018].

2015a. MOFA Brief on Emirati Women Empowerment on the Occasion of International Women's Day. Abu Dhabi. At https://www.mofa.gov.ae/EN/Documents/4114.pdf [Accessed on 23 August 2018].

2015b. MOFA Brief on Emirati Woman's Day. Abu Dhabi, 27 August. At https://www.mofa. gov.ae/SiteCollectionDocuments/27082015-WDe.pdf [Accessed on 20 January 2018].

Neumann, Iver B and Benjamin De Carvalho. 2015. 'Introduction: Small states and status.' In Benjamin de Carvalho and Iver B Neumann (eds), Small State Status Seeking. Norway's Quest for International Standing. New York/Abingdon: Routledge, pp. 1-21.

Petö, Andrea and Ian Manners. 2006. 'The European Union and the value of gender equality.' In Sonia Lucarelli and Ian Manners (eds), Values and Principles in European Union Foreign Policy. London/ New York: Routledge.

$\mathrm{Pu}$, Xiaoyu. 2017. 'Ambivalent accommodation: Status signalling of a rising India and China's response.' International Affairs 93 (1): 147-163.

$\mathrm{Pu}$, Xiaoyu and Randall L Schweller. 2014. 'Status signaling, multiple audiences, and China's blue-water naval ambition.' In T V Paul, Deborah Welch Larson and William C Wohlforth (eds), Status in World Politics. Cambridge: Cambridge University Press, pp. 141-164.

Renshon, Jonathan. 2017. Fighting for Status. Hierarchy and Conflict in World Politics. Princeton/ Oxford: Princeton University Press.

Sim, Li-Chen. 2012. 'Re-branding Abu Dhabi: From oil giant to energy titan.' Place Branding and Public Diplomacy 8: 83-98.

Tajfel, Henri and John Turner. 1986. 'The Social Identity Theory of Intergroup Behavior.' In Stephen Worshel and William Austin (eds.), Psychology of Intergroup Relations. Chicago: Nelson Hall, pp. 7-24.

Tajfel, Henri. 1982. 'Social psychology of intergroup relations.' Annual Review of Psychology 33: 1-39.

Tharoor, Ishaan. 2014. 'U.A.E.'s first female fighter pilot dropped bombs on the Islamic State.' The Washington Post [online], 25 September. At https://www.washingtonpost.com/news/worldviews/ wp/2014/09/25/u-a-e-s-first-female-fighter-pilot-dropped-bombs-on-the-islamic-state/?utm_ter$\mathrm{m}=.673247 \mathrm{c57968}$ [Accessed on 9 January 2018].

The World Bank. 2017. 'United Arab Emirates. Labor force, female (\% of total labor force).' At https:// data.worldbank.org/indicator/,SL.TLF.TOTL.FE.ZS?locations=AE [Accessed on 24 August 2018]. 
Towns, Ann. 2016. 'Civilization.' In Lisa Disch and Mary Hawkesworth (eds), Oxford Handbook on Feminist Theory. Oxford: Oxford University Press, pp. 79-99.

. 2007. 'The status of women and the ordering of human societies along the stages of civilization.' In Martin Hall and Patrick Thaddeus Jackson (eds), Civilizational Identity: The Production and Reproduction of “Civilizations" in International Relations. Basingstoke: Palgrave, pp. 167-179.

Underwood, Mitya. 2014. 'Baby steps to better health for mothers and children.' The National [online], 30 November. At https://www.thenational.ae/uae/baby-steps-to-better-health-for-mothersand-children-1.633273 [Accessed on 9 January 2018].

Vision 2021 [online]. 2018. UAE Vision 2021. At https://www.vision2021.ae/en [Accessed on 30 January 2018].

Volgy, Thomas Renato Corbetta, Ryan Baird and Keith A Grant (eds). 2011. Major Powers and the Quest for Status in International Politics. Global and Regional Perspectives. Basingstoke: Palgrave MacMillan.

WAM. 2015a. 'UN selects Ohood al-Roumi as first Arab member of global entrepreneurship council.' UAE Interact [online], 18 October. At http://www.uaeinteract.com/docs/UN_selects_Ohood_ Al_Roumi_as_first_Arab_member_of_Global_Entrepreneurship_Council/71740.htm [Accessed on 31 October 2015].

2015b. 'First Emirati woman appointed for an international position at the headquarters of the United Nations in New York.' UAE Interact [online], 22 September. At http://www.uaeinteract. com/docs/First_Emirati_woman_appointed_for_an_international_position_at_the_headquarters_of_the_United_Nations_in_New_York/71200.htm [Accessed on 31 October 2015].

Ward, Steven. 2017. 'Lost in translation: Social Identity Theory and the study of status in world politics.' International Studies Quarterly 61: 821-834.

Weiss, Yoram and Chaim Fershtman. 1998. 'Social status and economic performance: A survey'. European Economic Review 42: 801-820.

Wohlforth, William C, Benjamin de Carvalho, Halvard Leira and Iver B Neumann. 2017. 'Moral authority and status in International Relations: Good states and the social dimension of status seeking.' Review of International Studies 44 (3): 526-546.

Wolf, Reinhard. 2011. Respect and disrespect in international politics: The significance of status recognition. International Theory 3: 105-142.

World Economic Forum. 2017a. ‘Global Gender Gap Report. Shareable Infographics.' At http://reports.weforum.org/global-gender-gap-report-2017/shareable-infographics/ [Accessed on 18 January 2018].

2017b. 'Performance by Region and Country'. At http://reports.weforum.org/global-gender-gap-report-2016/performance-by-region-and-country/ [Accessed on 18 January 2018].

Zarakol, Ayşe. 2011. After Defeat. How the East Learned to Live with the West. Cambridge: Cambridge University Press.

2014. 'What made the modern world hang together: Socialisation or stigmatisation?' International Theory 6 (2): 311-332. 


\section{About the author}

Vânia Carvalho Pinto is a Professor at the Institute of International Relations at the University of Brasília, as well as an Academic Productivity Fellow for the Brazilian National Council of Research. She pursued her undergraduate studies in International Relations at the University of Coimbra (Portugal) and at the University of Leiden (Netherlands); obtained a Master's Degree in Middle Eastern Studies from the University of Exeter (UK); and a PhD in International Relations from the University of Hildesheim (Germany). She is the author of several articles and book chapters focusing on gender issues, Gulf Arab politics, and Latin America and Gulf Arab Relations. Her current research interests focus on the status-seeking policies of small states. 


\section{Sinalizando Status: EAU e Direitos das Mulheres}

Resumo: Que as sociedades se deveriam pautar pela igualdade de gênero é um ideal normativo forte ao qual os estados costumam subscrever, nem que seja apenas verbalmente. Os Emirados Árabes Unidos, como um estado altamente globalizado e que aspira a um status superior, não estão excluídos desta dinâmica. Se nas décadas seguintes à independência, obtida em 1971, os direitos das mulheres tinham sido enfatizados como um sinal de progresso do país; hoje o governo dos EAU afirma que aqueles são de tal forma avançados que estão a estabelecer uma nova referência de empoderamento de gênero para a região do Oriente Médio. Além disso, os EAU também proclamaram o objetivo de pertencerem, até 2021, ao grupo dos vinte cinco primeiros países do mundo que são considerados gender-equal. Sugiro que essas proclamações oficiais são parte importante de uma estratégia de sinalização cujo objetivo é advogar, perante uma audiência internacional, que os EAU merecem um status superior àquele que detêm atualmente. Com base na interpretação apresentada por Larson e Svechenko da teoria da identidade social, proponho que a estratégia dos EAU neste quesito pode ser definida em termos de criatividade social. Esta estratégia baseia-se na criação de um novo valor - o padrão Emirati de igualdade de gênero - dentro do grupo dos países árabes. Aquela é operacionalizada através de, por um lado, táticas de 'ensinar para o teste' na área da participação política das mulheres, campo este que pode ser regulado facilmente pelo governo; e por outro, no ênfase excessivo atribuído às realizações profissionais de um pequeno grupo de mulheres altamente bem sucedidas. Neste último caso, como os números de emprego feminino são bastante baixos, o governo elege chamar a atenção para mulheres em posições profissionais específicas e não convencionais, como um modo de atribuir maior credibilidade à existência de seu próprio padrão superior de igualdade de gênero na região árabe.

Palavras-chave: Emirados Árabes Unidos; estratégias de busca de status; igualdade de gênero; padrão dos Emirados; sinalização de status, direitos das mulheres.

Received on 1 February 2018, and approved for publication on 28 January 2019. 


\section{ERRATUM}

On article 'Signalling for Status: UAE and Women's Rights', with DOI number 10.1590/ S0102-8529.2019410200006, published on Contexto Internacional, 41(2): 345-363, on page 345:

Where it reads:

"Vânia Carvalho PINTO"

Should read:

"Vânia CARVALHO PINTO"

On page 362, where it reads:

"About the authors"

Should read:

"Acknowledgements

The research for this article was made possible thanks to the generous assistance of FAP/ DF, process no 0193.001252/2016.

\section{About the authors"}

